\title{
Idiosyncratic Effect of Corporate Solvency Management Strategies on Corporate Performance Valuation - A Study of Chemical Industry
}

\author{
Qaisar A. Malik, Dr. M. I. Saif \\ Assistant Professor, Department of Business \& Economics, FURC \\ Professor, HOD - Department of Humanities \& Social Sciences, Bahria University
}

\begin{abstract}
The study identifies and evaluates the association among corporate solvency management strategies and the corporate performance valuation in Chemical industry of Pakistan. The study uses purposive sampling or judgmental sampling for selecting 30 sample companies from the sector; covering 10 years financial statements data ranging from year 2002 to 2011. Balanced panel data is taken for the purpose of study. Levin, Lin \& Chu test is used to check the stationarity of data whereas White Test is used to check the heteroskedasticity of data. Panel Least square technique with fixed effects is used to generalize the relationship between studied variables. The study observed that the performance of the chemical sector in terms of market to book value is affected by internal firm and industry specific factors related to solvency management strategic decisions. Findings of the study provide with the overview of historic performance and the potential performance of the selected sector to help policy makers including finance, economics and industry experts for creating value through the idiosyncratic resources.
\end{abstract}

Keywords: Corporate Performance, Corporate Strategy, Solvency

\section{Introduction}

Capital market has been a significant part of the financial sector of the economy and an imperative gauge to identify and evaluate the status of the economy. Its efficiency along with other factors also very much depends on the level of information available to the investors; who use this information mostly through financial statements for enhancing their returns (Zeytinoglu et al, 2012). Hence the factors affecting the stock returns become the most significant aspect of empirical research in finance. The inter linkages between the corporate financial strategies representing the firm specific factors and the outcomes of those in terms of market value have to be understood and accordingly optimally utilized for the increased market value of the firms. Therefore every corporate organization is assumed to develop and implement such financial strategies which could actually help in maximizing the value for shareholders.

\section{Objectives of the Study}

The primary objective of the study is to identify and evaluate the association among corporate solvency management strategies and the corporate performance valuation. The study intends to contribute to the construct validity of solvency management indicators and their impact on corporate performance.

\section{Significance of the Study}

The study will check and evaluate the susceptibility of corporate sector's performance in response to corporate solvency management strategies; being of great use to finance, economics and industry experts.

\section{Literature Review}

Corporate strategic decisions have to be integrated and synchronized with corporate financial decisions to avoid financial distress and bankruptcy (Mubashir et al., 2012). This study discusses the corporate financial strategies regarding solvency management that are significant for adding value to the business (Kim et al., 1998; Chathoth \& Olsen, 2007; Su \& Vo, 2010). The strategic management literature emphasized much on exploring the factors affecting firms' performance across firms and across industry (Jibao \& Kai, 2010). The financial performance of firms is dependent on corporate financial strategies regarding the assets to be held and financing of the held assets (Kochhar, 1997). The resource based view also supports that the firm specific factors are significant for value creation through the idiosyncratic resources (McGahan and Porter, 2002; Hawawini et al., 2003; Ruefli \& Wiggins, 2003; Mcnamara et al., 2005; Hough, 2006). Corporate capital structure decisions reflecting the corporate solvency management strategies has always been the most debatable issue in finance literature and has evolved as the most researched and interesting area in finance (Karadeniz et al., 2009; 
Chakraborty, 2010) yet there is a question mark on the effect of capital structure on corporate performance . In a nut shell, capital structure studies can be divided into two schools of thoughts the relevance theory or the static trade off theory the irrelevance theory or the pecking order theory of capital structures for corporate valuation. The former is supported by Myers (1984), Roden \& Lewellen (1995), Champion (1999), Gosh et al. (2000), Booth et al. (2001), Hadlock \& James (2002), Fama \& French (2002), Frank \& Goyal (2003), Abor (2005), Huang \& Song (2006), Eriotis et al. (2007), Xiaoyan (2008), Jasim (2009), Pinar (2009), Chakraborty (2010), Bistrova et al. (2011), Azhagaiah (2011), Javid \& Imad (2012), Heydar et al. (2012), Uwalomwa \& Uadiale (2012), Mahdi \& Zinat (2012), Darush (2012), Faruk \& Ayub (2012), Salawu et al. (2012) and Nour (2012). The later is supported by Myers (1984), Rajan \& Zingales (1995), Wiwattanakantang (1999), Booth et al. (2001), Chiang et al. (2002), Fama \& French (2002), Deesomsak et al. (2004), Abor (2005), Huang \& Song (2006), Zeitun \& Tian (2007), Eriotis et al. (2007), Richard (2008), Mehmet \& Eda (2008), Arbabiyan \& Safari (2009), Karadeniz et al. (2009), Suhaila \& Wan (2009), Faris (2011), Memon et al. (2011), Sebastian \& Rapuluchukwu (2012) and Khan (2012). Yet there are many studies, including Tang \& Jang (2007), Mehmet \& Eda (2008), Ebaid (2009), Dimitrios et al. (2009), Darush (2012), Faruk \& Ayub (2012) and Mahdi \& Zinat (2012) showing a very weak or insignificant impact of capital structure on corporate performance. This shows that until today there has been a mired controversy in the studies conducted to advocate the acceptability and applicability of one school of thought over the other one. Owing to the mixed results, the studying of empirical relationships between capital structure and firm performance still holds logical (Ebaid, 2009). Further, though such empirical relationships have been tested in mature capital markets, yet the emerging markets have a lot of potential to be explored in such context to further generalize the earlier findings (Ebaid, 2009). Such controversy and debate arises the need to explore the variables in Pakistani context for different sectors of the industry to see how changes in capital structure affects the corporate performance in an emerging capital market of Pakistan.

\section{Methodology}

On the basis of the review of the literature, the study employs the following methodology to develop the construct solvency management and to measure the relationship between the studied construct and its impact on corporate performance valuation.

\section{Operationalization of Variables \& Development of Hypotheses \\ Dependent Variable - Corporate Performance Valuation}

Corporate performance valuation is measured through market to book - Tobin's Q. Tobin's Q is an extensively used score for measuring corporate performance and estimating the value of stock as against its replacement cost (Short, 2012).

\section{Independent Variable - Solvency Management}

Solvency analysis is conducted to determine how far a company is financially stable or otherwise in payment of the principal amount of long term funds they have borrowed; along with the capability of the firm to service the debt over its life in terms of interest payments. Hence following the earlier studies and their methodologies it is measured through debt to equity ratio and interest coverage ratio.

Hypotheses: The review of the literature allows developing the following hypotheses for evaluating the effect of solvency position on corporate performance valuation.

H1 Firms with high debt to equity tend to have high market to book value

$\mathrm{H} 2$ Firms with high interest coverage tend to have high market to book value

\section{Measurement of Variables}

On the basis of the review of literature the variables of the study are measured as follows:

\begin{tabular}{|l|l|l|}
\hline Constructs & Variables & Measurements \\
\hline Solvency & Debt Equity (DE) & Total Debt/Total Equity \\
\cline { 2 - 3 } & Interest Coverage (IC) & Operating Profit/Financial Charges \\
\hline $\begin{array}{l}\text { Corporate } \\
\text { Performance }\end{array}$ & $\begin{array}{l}\text { Market to Book (MB)/ } \\
\text { Tobin's Q }\end{array}$ & Market Value Per Share/Book Value Per Share \\
\hline
\end{tabular}

Population \& Sample of the Study 
The population of the study is Chemical industry of Pakistan. The study uses purposive sampling or judgmental sampling; a non probability sampling technique for selecting sample companies; based on the knowledge of the population and the purpose of the study.

\section{Population \& Sample Distribution}

\begin{tabular}{|l|l|l|l|l|}
\hline Sector & $\begin{array}{l}\text { Listed } \\
\text { Companies }\end{array}$ & $\begin{array}{l}\text { Deselected } \\
\text { Companies }\end{array}$ & $\begin{array}{l}\text { Selected } \\
\text { Companies }\end{array}$ & $\begin{array}{l}\text { Sample } \\
\text { Size }\end{array}$ \\
\hline Chemical & 43 & 13 & 30 & $70 \%$ \\
\hline
\end{tabular}

\section{Period of study}

The study took 10 years data from the financial statements of the selected 30 companies; covering years 2002 to 2011 . Hence 300 firm years data is used for measuring and analyzing the relationships between the studied variables.

\section{Data Collection}

Financial statements data is collected through "Financial Statements Analysis of Nonfinancial Companies Listed at Karachi Stock Exchange"; published by the Statistics \& Data Warehouse Department of State Bank of Pakistan.

\section{Data Analysis Techniques}

Balanced panel data is taken for the purpose of study. Both descriptive and inferential statistics are used to analyze the data and generalize the results. Most commonly used descriptive statistics measures for secondary data are mean, median, standard deviation, skewness and kurtosis. The present study will use Levin, Lin \& Chu (2002) test to check the stationarity of data. The reliability and validity of the model increases when the data is stationary. The study uses White Test (1980) to check the heteroskedasticity of data. The reliability and validity of the model increases when the data is free from heteroskedasticity problems. Panel least square fixed effect model is used after adjusting for heteroskedasticity of data to measure the impact of independent variables on dependent variable.

\section{Data Analysis}

Solvency \& Corporate Performance Analysis

Table 1: Panel Descriptive Statistics - Solvency \& Corporate Performance

\begin{tabular}{|l|l|l|l|}
\hline & MB & DE & IC \\
\hline Mean & 2.322745 & 5.049050 & 31.85593 \\
\hline Median & 1.302700 & 1.026500 & 3.802800 \\
\hline Std. Dev. & 6.060851 & 60.16123 & 94.70815 \\
\hline Skewness & 11.34095 & 17.20827 & 5.797473 \\
\hline Kurtosis & 159.5298 & 297.4165 & 46.37855 \\
\hline Observations & 300 & 300 & 300 \\
\hline
\end{tabular}

Source: Secondary Data

The above table indicates that DE and IC are positively skewed and leptokurtic. Mean values indicate that overall solvency position is satisfactory in terms of IC but quite weak in terms of DE. Median values reflect reasonably satisfactory solvency position in terms of IC but slightly weak solvency position in terms of DE. The highly debt financed outliers have caused the mean DE to be quite high. Higher standard deviation of the variables is also due to these outliers.

\section{Table 2: Levin, Lin \& Chu - Unit Root Test - Solvency \& Corporate Performance}

Null Hypothesis: Unit root (common unit root process)

Sample: 20022011

Exogenous variables: Individual effects

Automatic selection of maximum lags

Automatic selection of lags based on SIC: 0 to 1

Newey-West bandwidth selection using Bartlett kernel

Cross-sections included: 30

\begin{tabular}{|l|l|l|l|}
\hline Method & Variable & Statistic & Probability \\
\hline
\end{tabular}




\begin{tabular}{|l|l|l|l|}
\hline Levin, Lin \& Chu t* & MB & 8.53339 & 0.0000 \\
\hline Levin, Lin \& Chu t* & DE & -3.47585 & 0.0003 \\
\hline Levin, Lin \& Chu t* & IC & -13.1080 & 0.0000 \\
\hline
\end{tabular}

Source: Secondary Data

The Levin, Lin \& Chu test suggest the rejection of null hypothesis of presence of unit root.

Table 3: Panel Least Square-Fixed Effects Model-Solvency \& Corporate Performance

Dependent Variable: MB

Method: Panel Least Squares

Sample: 20022011

Cross-sections included: 30

Total panel (balanced) observations: 300

White cross-section standard errors \& covariance (d.f. corrected)

\begin{tabular}{lllll}
\hline \hline Variable & Coefficient & Std. Error & t-Statistic & Prob. \\
\hline \hline $\mathrm{C}$ & -0.127351 & 0.134394 & -0.947593 & 0.3442 \\
$\mathrm{DE}$ & 0.430119 & 0.086605 & 4.966425 & 0.0000 \\
$\mathrm{IC}$ & 0.170816 & 0.043523 & 3.924718 & 0.0001 \\
\hline \hline
\end{tabular}

Effects Specification

Cross-section fixed

\begin{tabular}{llll}
\hline \hline R-squared & 0.749933 & F-statistic & 25.92620 \\
Adjusted R-squared & 0.721007 & Prob (F-statistic) & 0.000000 \\
\hline \hline
\end{tabular}

Source: Secondary Data

The significance of t-statistics depicts that DE and IC are significant predictors of MB. Coefficients depict that DE and IC are positively linked with MB. Adjusted R2 tells that almost $72 \%$ of the variation in MB is explained by variation in DE and IC. The significance value of F statistics endorses the overall fitness of the model. As per the fixed effects model results $\mathrm{H} 1 \& \mathrm{H} 2$ are accepted. Mathematically the relationships may be expressed as:

$$
\begin{aligned}
& L S(C X=F, C O V=C X W H I T E) M B D E I C \\
& M B=C(1)+C(2) * D E+C(3) * I C+[C X=F] \\
& M B=-0.1273+0.4301 * D E+0.1708 * I C+[C X=F]
\end{aligned}
$$

\section{Discussion Of Results}

Since due to low solvency; the below average companies from chemical and allied sector are facing solvency risk or in other words they have more inclination towards relying on external financing (long term and short term finances) rather than internal financing (shareholders' equity); therefore such companies may face lower profitability due to higher reliance on external financing carrying fixed obligatory interest payments as against the internal financing carrying varying and optional dividend payments. The increased burden of interest payment due to heavy debt financing decreases the profitability of the companies on one side yet it increases the cash inflows due to tax advantages associated with such high debt financing, thus ultimately increase the returns for the owners of the companies despite their lower investments. Hence present debt financing levels at chemical and allied sectors is needed to be carefully reviewed; to financially evaluate the costs of debts as against the returns generated on those funds. As long as the returns exceed the costs; debt financing may be continued otherwise there is a serious need of restructuring the debt equity mix, since the higher debt to equity ratio may lead the chemical and allied industry towards insolvency and eventual bankruptcy especially for the outliers.

\section{Conclusion}

The present study observed that the performance of the chemical sector in terms of market to book value is affected by solvency management strategies and decisions, hence the sector need to perceive clearly about how their solvency management strategies would affect their performance and the valuation. The study 
identified, measured and evaluated the association between the variables and contributed to the construct validity of solvency management decisions and their impact on corporate performance. Moreover the study determined the predictability of certain solvency management indicators for measuring corporate performance and suggested what combination of these indicators may lead to improved corporate performance in future.

\section{References}

[1] Abor, J. (2005), The effect of capital structure on profitability: an empirical analysis of listed firms in Ghana, Journal of Risk Finance, Vol. 6, Iss: 5, pp.438 - 445.

[2] Arbabiyan, A. A. \& Safari, M. (2009), The effects of capital structure and profitability in the listed firms in Tehran Stock Exchange, Journal of Management Perspective, Vol. 33, pp. 159-175.

[3] Azhagaiah, R. \& Gavoury, C. (2011), The impact of capital structure on profitability with special reference to IT industry in India, http://www.fm-kp.si/zalozba/ISSN/1581-6311/9_371-392.pdf

[4] Bistrova, J., Lace, N. \& Peleckiené, V. (2011), The influence of capital structure on Baltic corporate performance, Journal of Business Economics and Management, Volume 12(4), 655-669

[5] Booth, L., Aivazian, V., Hunt, A. \& Maksimovic, D. (2001), Capital structure in developing countries, Journal of Finance, Vol. 56, pp. 87-130.

[6] Chakraborty, I. (2010), Capital structure in an emerging stock market: The case of India, Research in International Business and Finance, Vol. 24, pp. 295-314.

[7] Champion, D. (1999), Finance: the joy of leverage, Harvard Business Review, Vol. 77, pp. 19-22.

[8] Chang, H.L, Chen, Y. S., Su, C. W. \& Chang, Y. W. (2008), The relationship between stock price and EPS - evidence based on Taiwan panel data, Economics Bulletin, vol.30, issue.3, 1-12.

[9] Chathoth, P. K., \& Olsen, M. D. (2007). The effect of environment risk, corporate strategy, and capital structure on firm performance: An empirical investigation of restaurant firms. International Journal of Hospitality Management, 26(3)(3), 502-516.

[10] Darush, Y. (2012), The impact of financing pattern on firm growth: evidence from Swedish micro firms, International Business Research; Vol. 5, No. 9

[11] Deesomsak, R. \& Chau, F. (2011), The determinants of working capital management: evidence from Thailand, Proceedings of World Business Economics and Finance Conference

[12] Dimitrios, V., Eriotis, N. \& Daskalakis, N. (2009), Testing the pecking order theory: the importance of methodology, Qualitative Research in Financial Markets, Vol. 1 Iss: 2, pp.85 - 96.

[13] Ebaid, E. I. (2009), The impact of capital structure choice on firm performance: empirical evidence from Egypt, The Journal of Risk Finance, Vol. 10, No. 5, pp. 477-487.

[14] Eriotis, N., Vasiliou, D. \& Neokosmidi, Z. V. (2007), How firm characteristics affect capital structure: an empirical study, Managerial Finance, Vol. 33 Iss: 5, pp.321 - 331.

[15] Fama, E. \& French, R.K. (2002), Testing trade off and pecking order predictions about dividends and debt, The Review of Financial Studies, Vol. 15 No. 1, pp. 1-33.

[16] Faris, M. A. M. (2011), The determinants of capital structure of Palestine-listed companies, Journal of Risk Finance, Vol. 12, Iss: 3, pp. $226-241$

[17] Faruk, M. H., \& Ayub, M. A. (2012), Impact of firm specific factors on capital structure decision: an empirical study of Bangladeshi companies, International Journal of Business Research and Management, Volume 3, Issue 4

[18] Frank, M. Z. \& Goyal, V. K. (2009), Profits and capital structure, AFA 2009, San Francisco Meetings Paper, http://ssrn.com/abstract=1104886

[19] Ghosh, C., Nag, R. \& Sirmans, C. (2000), The pricing of seasoned equity offerings: evidence from REITs, Real Estate Economics, Vol. 28, pp. 363-84.

[20] Hadlock, C. \& James, C. (2002), Do banks provide financial slack?, Journal of Finance, Vol. 57, pp. 1383-420.

[21] Hawawini, G., Subramanian, V. \& Verdin, P. (2003), Is performance driven by industry or firm specific factors? A new look at the evidence, Strategic Manaement Journal, Volume 24, Number 1, 1-16

[22] Heydar, M. S., Elham, G., Vahid, T. K. \& Mohsen, A. K. (2012), Capital structure and firm performance; evidence from Tehran Stock Exchange, 2nd International Conference on Financial Management and Economics, http://www.ipedr.com/vol43/046ICFME2012-X10025.pdf

[23] Hough, J. R. (2006), Business segment performance redux: a multilevel approach, Strategic Management Journal, Volume 27, Number 1, pp 45-48.

[24] Huang, S. \& Song, F. (2006), The determinants of capital structure: evidence from China, China Economic Review, Vol. 17 No. 1, pp. 14-36.

[25] Jasim, A., Hussain, H. \& Nadhem, A. (2009), Decisions on capital structure in a Zakat environment with prohibition of riba: The case of Saudi Arabia, Journal of Risk Finance, Vol. 10, Iss: 5, pp.460 - 476.

[26] Javid, A. Y. \& Imad, Q (2012), A decomposition analysis of capital structure: evidence from Pakistan's manufacturing sector, The Lahore Journal of Economics, $17: 1$, pp. 1-31

[27] Jibao, G. \& Kai, G. (2010), The determinants of firm performance: the industry factors or the firm factors? an empirical research on the listed companies in China, International Journal of Networking and Virtual Organisations, Volume 7, Number 4, 366-380

[28] Karadeniz, E., Kandir, Y. S., Balcilar, M. \& Onal, B. Y. (2009), Determinants of capital structure: evidence from Turkish lodging companies, International Journal of Contemporary Hospitality Management, Vol. 21, No. 5, pp. 594-609.

[29] Khan, A. G. (2012), The relationship of capital structure decisions with firm performance: A study of the engineering sector of Pakistan, International Journal of Accounting and Financial Reporting, Vol. 2, No. 1

[30] Kim, S. J. \& Mark, R. S. (1999), Corporate leverage, wasteful capital sales, and output adjustment in East Asia, Washington: International Monetary Fund.

[31] Kochhar, R. (1997), Strategic assets, capital structure, and firm performance, Journal Of Financial And Strategic Decisions, Volume 10 , Number 3

[32] Mahdi, K. \& Ansari, Z (2012), The impact of firm characteristics on capital structure of listed companies in Tehran Stock Exchange, American Journal of Scientific Research, Issue 42, pp. 12-23

[33] McGahan, A. \& Porter, M. (1997), How much does industry matter, really? Strategic Management Journal, Volume 18, Number S1, $15-30$

[34] Mcnamara, G., Aime, F. \& Vaaler, M. Is performance driven by industry or firm-specific factors? A response to Hawawini, Subramanian and Verdin, Strategic Management Journal, Volume 26, Number 11, pp 1075-1081. 
[35] Mehmet, S. \& Eda, O. (2008), Testing of Pecking Order Theory in ISE (Istanbul Stock Exchange Market), International Research Journal of Finance and Economics, Issue 21

[36] Memon, F., Bhutto, N. A. \& Abbas, G. (2012), Capital structure and firm performance: a case of textile sector of Pakistan, Asian Journal of Business and Management Sciences, Vol. 1, No. 9, 09-15

[37] Mubashir, A. Raheman, A \& Zulfiqar, B (2012), Co- Alignment among corporate strategy, financial structure and firm performance in non-financial sector of Pakistan, Journal of Basic and Applied Scientific Research, 2(7), 7107-7114.

[38] Myers, S.C. \& Majluf, N.S. (1984), Corporate financing and investment decisions when firms have information that investors do not have, Journal of Financial Economics, Vol. 13 No. 2, pp. 187-221.

[39] Nour, A. (2012), Capital structure and firm performance; evidence from Palestine Stock Exchange, Journal of Money, Investment and Banking, Issue 23, http://www.journalofmoneyinvestmentandbanking.com

[40] Pinar, E. M. (2009), Testing capital structure models for Turkish non-financial firms: the analysis of firm-specific financial factors and agency variables, Investment Management and Financial Innovations, Volume 6, Issue 1

[41] Rajan, R. \& Zingales, L. (1995), What do we know about capital structure? Some evidence from international data, The Journal of Finance, Vol. 50, pp. 1421-60.

[42] Richard, H. F. (2008), Debt capacity and debt financing, Journal of Business \& Economics Research, Volume 6, Number 8

[43] Roden, D. \& Lewellen, W. (1995), Corporate capital structure decisions: evidence from leveraged buyouts, Financial Management, Vol. 24, pp. 76-87.

[44] Ruefli, T. W. \& Wiggins, R. R. (2003), Industry, corporate, and segment effects and business performance: a non-parametric approach, Strategic Management Journal, Volume 24, Number 9, pp 861-879.

[45] Salawu, R. O., Asaolu, T. O. \& Yinusa, D. O. (2012), Financial policy and corporate performance: an empirical analysis of Nig erian listed companies, International Journal of Economics and Finance Vol. 4, No. 4

[46] Sebastian, O. U. \& Rapuluchukwu, U. E. (2012), The impact of capital structure and liquidity on corporate returns in Nigeria: evidence from manufacturing firms, International Journal of Academic Research in Accounting, Finance and Management Sciences, Volume 2, Issue 3

[47] Short, D (2012), The Q Ratio and Market Valuation: Monthly Update, http://www.advisorperspectives.com/dshort/updates/Q-Ratioand-Market-Valuation.php

[48] Su, G. S. \& Vo, H. T. (2010), The relationship between corporate strategy, capital structure and firm performance: an empirical study of the listed companies in Vietnam, International Research Journal of Finance and Economics, Issue 5.

[49] Suhaila, M. K. \& Wan, M. W. M. (2009), Capital structure and firm characteristics: some evidence from Malaysian companies, MPRA Paper No. 14616, http://mpra.ub.uni-muenchen.de/14616/

[50] Tang, C.H. \& Jang, S.S. (2007), Revisit to the determinants of capital structure: a comparison between lodging firms and soft ware firms, International Journal of Hospitality Management, Vol. 26 No. 1, pp. 175-87.

[51] Uwalomwa U. \& Uadiale, O. M. (2012), An empirical examination of the relationship between capital structure and the financial performance of firms in Nigeria, Euro Economica, Banking, Finance And Accounting, Issue 1(31)

[52] Wiwattanakantang, Y. (1999), An empirical study on the determinants of the capital structure of Thai firms, Pacific-Basin Finance Journal, Vol. 7, pp. 371-403.

[53] Xiaoyan, N. (2008), Theoretical and practical review of capital structure and its determinants, International Journal of Business and Management, March 2008

[54] Zeitun, R. \& Tian, G. G. (2007), Capital structure and corporate performance: evidence from Jordan, Australasian Accounting Business and Finance Journal, Volume 1, Issue 4, pp. 40-53.

[55] Zeytinoglu E., Akarim, Y. D. \& Çelik, S. (2012), The impact of market-based ratios on stock returns: the evidence from insurance sector in Turkey, International Research Journal of Finance and Economics, ISSN 1450-2887, Issue 84 (2012), 41-48. 